work of the Commission irrelevant. While many services work under pressure, we do not see that dealing with visits and complying with good practice are extraneous 'additional tasks' rather than essential functions of psychiatric units, nor do we resent the time necessarily required for this. We appreciate that in extreme cases of bad practice sanctions may be necessary, but we would not say that knowledge of these has caused 'great anxiety' for us or for our nonmedical colleagues. We support the response of the Chief Executive of the Commission (Psychiatric Bulletin, February 1998, 22, 119-121) and recognise that the work of the Commission is generally in patients' interests, and we note that reports from visits can often further our own arguments for better resources for patient care.

DAVID CURTIS, NICK BASS, ANDREW COBB, JAN Falkowski, Eleni Palazidou, Tim REad, and JOGIN THAKORE, Consultant Adult Psychiatrists, Tower Hamlets Healthcare Trust, Department of Adult Psychiatry. 3rd Floor Outpatient Building, The Royal London Hospital, E1 1BB

\section{Micro-titration of depot neuroleptic dosages}

Sir: A number of readers wrote to me in response to my article (Psychiatric Bulletin. November 1996, 20, 660-661) requesting the micro-titration software. I have not been able to respond to these requests because of a computer 'virus' at my workplace, followed by a theft of computer equipment. I am now in a position to write back to those who were interested in the software but as a result of the theft I no longer have their names and addresses. Please could those who are still interested send me their names and addresses again.

JIM BIRCH, Consultant Psychiatrist, North Shields Community Mental Health Team, Mental Health Division, North Tyneside, 26a Hawkeys Lane, North Shields NE29 OPN

\title{
Seminars in the Psychiatry of Learning Disabilities
}

\author{
Edited by Oliver Russell
}

This volume is both an up to date account of recent advances in the field of learning disabilities and a practical guide to the diagnosis and treatment of psychiatric disorder. Chapters on the classification of psychiatric disorders in people with learning disabilities, the epidemiology of intellectual disability and the diagnosis of psychiatric disorder are followed by more detailed accounts of autism, behavioural phenotypes and communication disorders. Psychiatric disorders are covered in the latter part of the book, including discussions on behavioural interventions, counselling and epilepsy. The book concludes with a review of forensic aspects of psychiatric management and treatment.

1997, 288pp, ISBN $0901242021, £ 15.00$

The College Seminars Series and other Gaskell publications are available from Booksales, Publications Department, Royal College of Psychiatrists, 17 Belgrave Square, London SWIX 8PG (Tel. +44(0)171 235 2351, extension 146). The latest information on College publications is available on the INTERNET at: http://www.rcpsych.ac.uk 